\title{
RE-DESAIN INTERIOR “HOTEL LAMPION” \\ DI SURAKARTA
}

\author{
Khoyrunnissa $^{1}$, Ahmad Fajar Ariyanto ${ }^{2}$ \\ Program Studi Desain Interior, \\ Fakultas Seni Rupa dan Desain, Institut Seni Indonesia (ISI) Surakarta \\ 'Email: khoyrunnissa@gmail.com \\ 2Email: fajar@isi-ska.ac.id
}

\begin{abstract}
Surakarta is a city of culture and tourism so many tourists arrive, therefore supporting facilities, especially hotels are needed. One of the hotels in Surakarta is the Lampion Hotel which is a 2-star hotel. The Lampion Hotel in Surakarta seeks to raise the standard from 2 stars to 3 stars to support the needs of its visitors. The Lampion Hotel in Surakarta requires interior redesign by adding some facilities and changing the hotel interior to be more local. Hotel Lantern in Surakarta as an effort to improve a 2-star hotel to a 3-star hotel by adding facilities at: Bars, suite rooms, drug stores, souvenir shops and sports facilities. Apart from the addition of several facilities, the Lantern Hotel also needs interior changes to make it a local image. Changes in the interior of the Lantern Hotel in Surakarta use the Grebeg Sudiro theme approach which is a national event originating from the city of Surakarta.
\end{abstract}

Keywords: Redesign, Lantern Hotel, Grebeg Sudiro

\section{PENDAHULUAN}

Surakarta dikenal sebagai kota yang memiliki banyak tempat pariwisata seperti wisata religi, wisata alam, wisata kuliner dan wisata budaya seperti kirab budaya dan wisata bangunan bersejarah, sehingga tumbuh beberapa fasilitas pendukung kepariwisataan salah satunya adalah hotel. Hotel berasal dari kata hostel yang artinya tempat penampungan diperkirakan hotel sudah ada sejak abad XVII ${ }^{1}$. Menurut SK menteri perhubungan No. PM 10 / PW. 391 / Phb-77 hotel adalah bentuk akomodasi yang dikelola secara komersial, disediakan bagi setiap orang untuk memperoleh pelayanan dikelola secara komersial, yang disediakan bagi setiap orang untuk memperoleh pelayanan, penginapan berikut makanan dan minuman. ${ }^{2}$ Berdasarkan pengertian di atas hotel merupakan tempat tinggal sementara yang menyediakan sarana

\footnotetext{
1 http://www.surakarta.go.id/konten/ slogan-surakarta/29-05-2016/09.00wib

2 Bambang Sujanto, Hotel Courtesy

The Secret of 5 Star Hotel Courtesy 2008.
}

makan dan minum yang dikelola secara komersial. Pertumbuhan hotel sebagai fasilitas pendukung pariwisata di Surakarta cukup tinggi ${ }^{3}$ sehingga banyak bermunculan hotel dari bintang satu hingga bintang lima, salah satu diantaranya yaitu Hotel Lampion di Surakarta.

Hotel Lampion di Surakarta adalah hotel dengan skala bintang dua yang beralamat di jalan Dr.Rajiman no.289 Surakarta. Hotel Lampion di Surakarta mulai beroperasi pada hari Jumat, 29 Juli 2011, mulanya bangunan yang digunakan menjadi Hotel Lampion di Surakarta adalah bangunan bank BHS yang mangkrak, yang kemudian berganti dengan hotel yang bernama@HOM Hotel yang dikelola oleh Metropolitan Golden Management (MQM) dengan direktur manager Vony Lukminto strategi @ HOM Hotel dalam pemasaran produk dan jasanya menawarkan harga bintang dua dengan fasilitas bintang tiga. Disebut bintang dua karena bertarif ekonomis sehingga para pengunjung

3 https://surakartakota.bps.go.id/pressrelease.html/ 25 Juli 2018/22.11 WIB 
dapat merasakan kualitas pelayanan bintang tiga. Pada tanggal 30 November 2011 @HOM melepaskan diri dari management MGM dan berganti nama menjadi Hotel Lampion di Surakarta. $^{4}$

Bangunan Hotel Lampion di Surakarta saat ini memiliki fasilitas restaurant, coffee shop, function room, laundry, dengan fasilitas kamar deluxe dan kamar superior. Interior hotel yang disajikan saat ini memiliki gaya modern dengan sentuhan budaya China maupun Jawa.

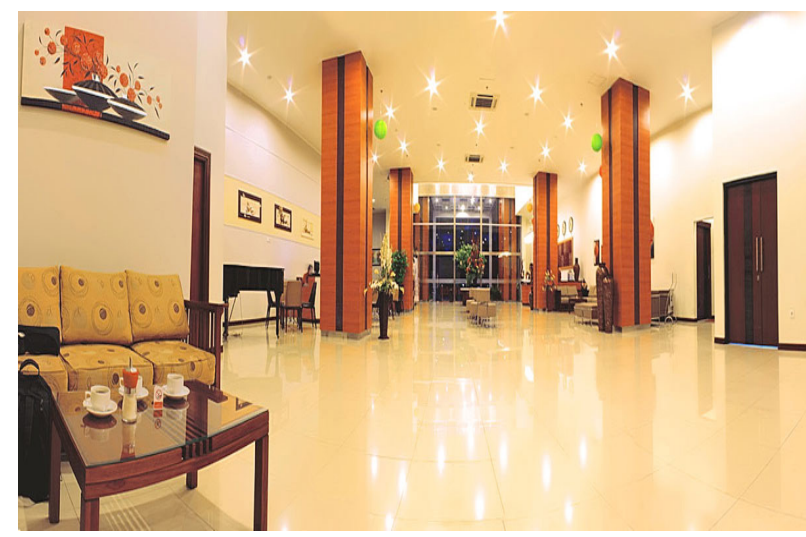

Gambar 1. Interior Lobby Hotel Lampion di Surakarta

(Foto : lampionhotelsolo.com)

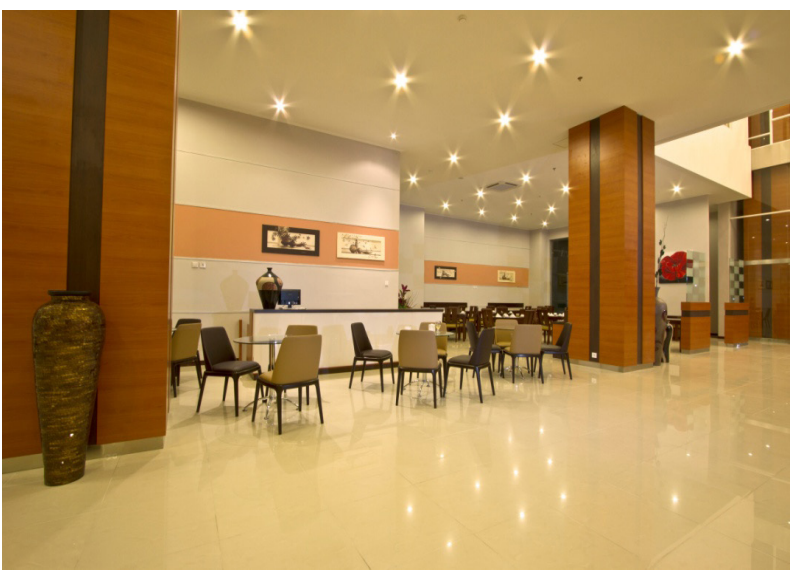

Gambar 2. Interior Restaurant Hotel Lampion di Surakarta (Foto : lampionhotelsolo.com)

4 https://lampionhotelsolo.com/11 Mei 2016/18.18 WIB
Berdasarkan hasil wawancara dengan pihak manajemen Hotel Lampion di Surakarta sebagai fasilitas akomodasi publik komersial, Hotel Lampion di Surakarta ingin meningkatkan kualitas dari bintang dua ke bintang tiga. ${ }^{5}$ Dilihat dari beberapa aspek klasifikasi hotel bintang tiga di Indonesia adalah adanya unsur dekorasi Indonesia (lokal) harus tercermin pada lobby, restaurant, kamar tidur dan function room. Tipe kamar Hotel Lampion di Surakarta memiliki 2 tipe yaitu Deluxe dan Superior menurut peraturan pemerintah tentang standar hotel bintang tiga seharusnya terdapat standard room dengan luas $22 \mathrm{~m}^{2}$ dan minimal terdapat 2 suite room dengan luas $44 \mathrm{~m}^{2}$. Fasilitas lain yang dipersyaratkan adalah adanya bar, drug store, souvenir shop dan sarana olahraga sedangkan pada Hotel Lampion di Surakarta bar, souvenir shop, sarana olahraga belum terdapat, sedangkan drug store pada Hotel Lampion di Surakarta berada pada zona privat yaitu office room sehingga perlu dipindahkan pada area publik agar mudah diakses oleh pengunjung.

Tahapan proses desain pada re-desain Interior Hotel Lampion di Surakarta mengacu pada pendapat Pamuji Subtandar yaitu :

(1)input, (2) sintesa dan (3) output. Input adalah pengumpulan data atau informasi yang dapat digunakan untuk mendapatkan permasalahan desain dan menentukan konsep pendekatan pemecahan desain. Didalam proses pengumpulan data banyak cara yang dapat digunakan seperti wawancara untuk mendapatkan data lapangan di Hotel Lampion di Surakarta, studi literatur untuk mendapatkan data tertulis dari buku referensi maupun internet, proses sosial untuk mendapatkan site plan. ${ }^{6}$

$5 \quad$ Joko, Surakarta, Supervisor Management Hotel Lampion, Surakarta. 2017

6 Pamudji Suptandar, Desain

Interior, 1999 


\section{PEMBAHASAN}

Re-desain Interior Hotel Lampion di Surakarta mempunyai arti kegiatan perencanaan dan perancangan kembali tatanan perabot yang ada didalam bentuk akomodasi yang dikelola secara komersial (Hotel Lampion) di salah satu kota yang berada di Jawa Tengah yang dikenal sebagai kota budaya dan pariwisata atau Surakarta. Re-desain interior Hotel Lampion di Surakarta ini bertujuan untuk meningkatkan kualitas hotel dari bintang dua menjadi hotel bintang tiga.

\section{Tinjaun interior Hotel Lampion di Surakarta}

Tinjaun interior Hotel Lampion di Surakarta mengacu pada :

1. Peraturan Menteri Pariwisata dan Ekonomi Kreatif Republik Indonesia Nomor PM.53/HM.001/MPEK/2013 Tentang Standard Usaha Hotel

2. Peraturan Usaha Dan Penggolongan Hotel Menurut Menteri Parpostel No. KM. 37/PW. 304/MPPT-86

3. Klarifikasi Hotel Berbintang Menurut Andy Marlina

Bangunan Hotel Lampion di Surakarta saat ini memiliki fasilitas restaurant, coffee shop, function room, laundry, dengan fasilitas kamar deluxe dan kamar superior. Bedasarkan acuan diatas untuk menjadi hotel berbintang 3 Hotel Lampion di Surakarta perlu menambahkan beberapa fasilitas yaitu bar, suite room, drug store, souvenir shop dan sarana olahraga. Interior hotel Lampion di Surakarta saat ini memiliki gaya modern dengan sentuhan budaya China maupun Jawa. Bedasarkan acuan diatas untuk menjadi hotel berbintang 3 Hotel Lampion di Surakarta perlu mengubah interior hotel dengan nuansa lokal. Pengkarya mengambil tema Grebeg Sudiro sebagai unsur lokal yang berada di Surakarta.

\section{Pengembangan Struktur Organisasi}

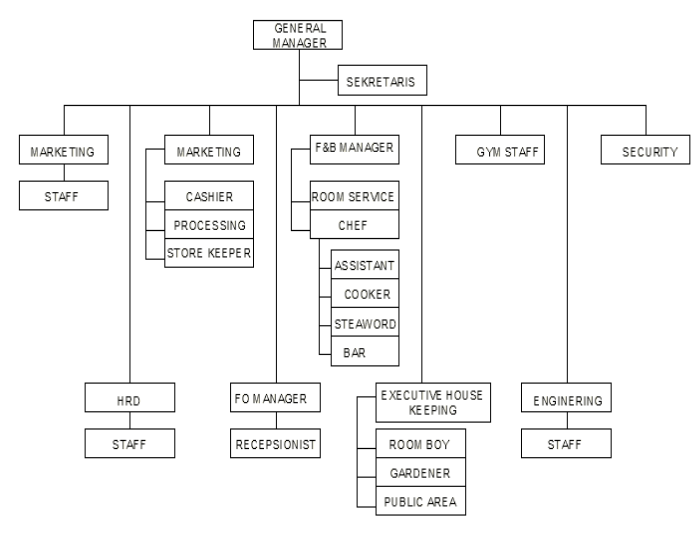

Gambar 3. Pengembangan Struktur Organisasi Hotel Lampion di Surakarta

\section{Aktivitas Pengguna dan Kebutuhan Ruang}

Tabel 1. Aktivitas pengguna dan kebutuhan ruang

\begin{tabular}{|c|c|c|c|c|}
\hline No & $\begin{array}{l}\text { Penggu- } \\
\text { na }\end{array}$ & Aktivitas & $\begin{array}{l}\text { Kebutuhan } \\
\text { ruang }\end{array}$ & Isian ruang \\
\hline 1. & $\begin{array}{l}\text { General } \\
\text { manager }\end{array}$ & $\begin{array}{l}\text { Bekerja } \\
\text { Rapat } \\
\text { Istirahat } \\
\text { Buang air } \\
\text { kecil atau } \\
\text { besar } \\
\text { B eriba- } \\
\text { dah }\end{array}$ & $\begin{array}{l}\text { Kantor } \\
\text { Ruang ra- } \\
\text { pat } \\
\text { Lavatory } \\
\text { Musholla }\end{array}$ & $\begin{array}{l}\text { Meja Kerja } \\
\text { Kursi Kerja } \\
\text { Almari } \\
\text { Arsip } \\
\text { Meja Pen- } \\
\text { gunjung } \\
\text { Meja Rapat } \\
\text { Rak } \\
\text { Closet } \\
\text { Washtafel }\end{array}$ \\
\hline
\end{tabular}




\begin{tabular}{|c|c|c|c|c|c|c|c|c|c|}
\hline 2. & $\begin{array}{l}\text { Sekretar- } \\
\text { is }\end{array}$ & $\begin{array}{l}\text { Bekerja } \\
\text { Rapat } \\
\text { Istirahat } \\
\text { Buang air } \\
\text { kecil atau } \\
\text { besar } \\
\text { Beriba- } \\
\text { dah }\end{array}$ & $\begin{array}{l}\text { Kantor } \\
\text { Ruang ra- } \\
\text { pat } \\
\text { Lavatory } \\
\text { Musholla }\end{array}$ & $\begin{array}{l}\text { Meja Kerja } \\
\text { Kursi Kerja } \\
\text { Almari } \\
\text { Arsip } \\
\text { Meja Pen- } \\
\text { gunjung } \\
\text { Meja Rapat } \\
\text { Rak } \\
\text { Closet } \\
\text { Washtafel }\end{array}$ & 5. & $\begin{array}{l}\text { Ac- } \\
\text { counting } \\
\text { manager }\end{array}$ & $\begin{array}{l}\text { Bekerja } \\
\text { Rapat } \\
\text { Istirahat } \\
\text { Buang air } \\
\text { kecil atau } \\
\text { besar } \\
\text { Beriba- } \\
\text { dah }\end{array}$ & $\begin{array}{l}\text { Kantor } \\
\text { Ruang ra- } \\
\text { pat } \\
\text { Lavatory } \\
\text { Musholla }\end{array}$ & $\begin{array}{l}\text { Meja Kerja } \\
\text { Kursi Kerja } \\
\text { Almari } \\
\text { Arsip } \\
\text { Meja Pen- } \\
\text { gunjung } \\
\text { Meja Rapat } \\
\text { Rak } \\
\text { Closet } \\
\text { Washtafel }\end{array}$ \\
\hline 3. & $\begin{array}{l}\text { Market- } \\
\text { ing }\end{array}$ & $\begin{array}{l}\text { Bekerja } \\
\text { Rapat } \\
\text { Istirahat } \\
\text { Buang air } \\
\text { kecil atau } \\
\text { besar } \\
\text { Beriba- } \\
\text { dah }\end{array}$ & $\begin{array}{l}\text { Kantor } \\
\text { Ruang ra- } \\
\text { pat } \\
\text { Lavatory } \\
\text { Musholla }\end{array}$ & $\begin{array}{l}\text { Meja Kerja } \\
\text { Kursi Kerja } \\
\text { Almari } \\
\text { Arsip } \\
\text { Meja Pen- } \\
\text { gunjung } \\
\text { Meja Rapat } \\
\text { Rak } \\
\text { Closet } \\
\text { Washtafel }\end{array}$ & 6. & $\begin{array}{l}\text { Store } \\
\text { keeper }\end{array}$ & $\begin{array}{l}\text { Bekerja } \\
\text { Rapat } \\
\text { Istirahat } \\
\text { Buang air } \\
\text { kecil atau } \\
\text { besar } \\
\text { Beriba- } \\
\text { dah }\end{array}$ & $\begin{array}{l}\text { R u a } \mathrm{n} g \\
\text { pen y i m- } \\
\text { panan } \\
\text { Ruang ra- } \\
\text { pat } \\
\text { Lavatory } \\
\text { Musholla }\end{array}$ & $\begin{array}{l}\text { Meja Kerja } \\
\text { Kursi Kerja } \\
\text { Almari } \\
\text { Arsip } \\
\text { Meja Pen- } \\
\text { gunjung } \\
\text { Meja Rapat } \\
\text { Rak } \\
\text { Closet } \\
\text { Washtafel }\end{array}$ \\
\hline 4. & $H R D$ & $\begin{array}{l}\text { Bekerja } \\
\text { Rapat } \\
\text { Istirahat } \\
\text { Buang air } \\
\text { kecil atau } \\
\text { besar } \\
\text { Beriba- } \\
\text { dah }\end{array}$ & $\begin{array}{l}\text { Kantor } \\
\text { Ruang ra- } \\
\text { pat } \\
\text { Lavatory } \\
\text { Musholla }\end{array}$ & $\begin{array}{l}\text { Meja Kerja } \\
\text { Kursi Kerja } \\
\text { Almari } \\
\text { Arsip } \\
\text { Meja Pen- } \\
\text { gunjung } \\
\text { Meja Rapat } \\
\text { Rak } \\
\text { Closet } \\
\text { Washtafel }\end{array}$ & 7. & Cashier & $\begin{array}{l}\text { Bekerja } \\
\text { Rapat } \\
\text { Istirahat } \\
\text { Buang air } \\
\text { kecil atau } \\
\text { besar } \\
\text { Beriba- } \\
\text { dah }\end{array}$ & 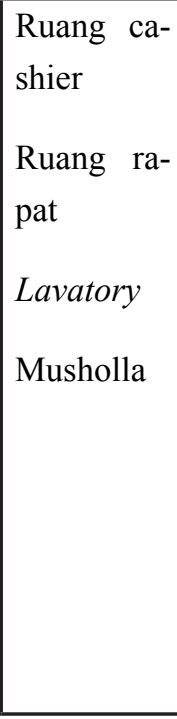 & $\begin{array}{l}\text { Meja Kerja } \\
\text { Kursi Kerja } \\
\text { Almari } \\
\text { Arsip } \\
\text { Meja Pen- } \\
\text { gunjung } \\
\text { Meja Rapat } \\
\text { Rak } \\
\text { Closet } \\
\text { Washtafel }\end{array}$ \\
\hline
\end{tabular}




\begin{tabular}{|c|c|c|c|c|}
\hline 8. & $\begin{array}{l}\text { Process- } \\
\text { ing }\end{array}$ & $\begin{array}{l}\text { Bekerja } \\
\text { Rapat } \\
\text { Istirahat } \\
\text { Buang air } \\
\text { kecil atau } \\
\text { besar } \\
\text { Beriba- } \\
\text { dah }\end{array}$ & $\begin{array}{l}\text { Kantor } \\
\text { Ruang ra- } \\
\text { pat } \\
\text { Lavatory } \\
\text { Musholla }\end{array}$ & $\begin{array}{l}\text { Meja Kerja } \\
\text { Kursi Kerja } \\
\text { Almari } \\
\text { Arsip } \\
\text { Meja Pen- } \\
\text { gunjung } \\
\text { Meja Rapat } \\
\text { Rak } \\
\text { Closet } \\
\text { Washtafel }\end{array}$ \\
\hline 9. & $\begin{array}{l}\text { FO man- } \\
\text { ager }\end{array}$ & $\begin{array}{l}\text { Bekerja } \\
\text { Rapat } \\
\text { Istirahat } \\
\text { Buang air } \\
\text { kecil atau } \\
\text { besar } \\
\text { Beriba- } \\
\text { dah }\end{array}$ & $\begin{array}{l}\text { Kantor } \\
\text { Ruang ra- } \\
\text { pat } \\
\text { Lavatory } \\
\text { Musholla }\end{array}$ & $\begin{array}{l}\text { Meja Kerja } \\
\text { Kursi Kerja } \\
\text { Almari } \\
\text { Arsip } \\
\text { Meja Pen- } \\
\text { gunjung } \\
\text { Meja Rapat } \\
\text { Rak } \\
\text { Closet } \\
\text { Washtafel }\end{array}$ \\
\hline
\end{tabular}

\begin{tabular}{|c|c|c|c|c|}
\hline 10. & $\begin{array}{l}\text { Receps- } \\
\text { ionist }\end{array}$ & $\begin{array}{l}\text { Melaku- } \\
\text { kan tran- } \\
\text { s a k s i } \\
\text { pe mba- } \\
\text { yaran } \\
\text { Meneri- } \\
\text { ma pen- } \\
\text { gunjung } \\
\text { Pemberi } \\
\text { informasi } \\
\text { Te m pat } \\
\text { pendaft- } \\
\text { a } r \text { a } n \\
\text { event } \\
\text { Rapat } \\
\text { Istirahat } \\
\text { Buang air } \\
\text { kecil atau } \\
\text { besar } \\
\text { Beriba- } \\
\text { dah }\end{array}$ & $\begin{array}{l}\text { Resepsio- } \\
\text { nis } \\
\text { Ruang ra- } \\
\text { pat } \\
\text { Lavatory } \\
\text { Musholla }\end{array}$ & $\begin{array}{l}\text { Meja Kerja } \\
\text { Kursi Kerja } \\
\text { Almari } \\
\text { Arsip } \\
\text { Meja Pen- } \\
\text { gunjung } \\
\text { Meja Rapat } \\
\text { Rak } \\
\text { Closet } \\
\text { Washtafel }\end{array}$ \\
\hline 11. & $\begin{array}{l}F \& B \\
\text { Manager }\end{array}$ & $\begin{array}{l}\text { Bekerja } \\
\text { 12.Rapat } \\
\text { Isti13. } \\
\text { rahat } \\
\text { Buang air } \\
\text { kecil atau } \\
\text { besar } \\
\text { Beriba- } \\
\text { dah }\end{array}$ & $\begin{array}{l}\text { Kantor } \\
\text { Ruang ra- } \\
\text { pat } \\
\text { Lavatory } \\
\text { Musholla }\end{array}$ & $\begin{array}{l}\text { Meja Kerja } \\
\text { Kursi Kerja } \\
\text { Almari } \\
\text { Arsip } \\
\text { Meja Rapat } \\
\text { Rak } \\
\text { Closet } \\
\text { Washtafel }\end{array}$ \\
\hline
\end{tabular}




\begin{tabular}{|c|c|c|c|c|}
\hline 12. & $\begin{array}{l}\text { Room } \\
\text { service }\end{array}$ & $\begin{array}{l}\text { Bekerja } \\
\text { (mem- } \\
\text { bersihkan } \\
\text { dapur) } \\
\text { Rapat } \\
\text { Istirahat } \\
\text { Buang air } \\
\text { kecil atau } \\
\text { besar } \\
\text { Beriba- } \\
\text { dah }\end{array}$ & $\begin{array}{l}\text { Ruang per- } \\
\text { alatan } \\
\text { Ruang ra- } \\
\text { pat } \\
\text { Lavatory } \\
\text { Musholla }\end{array}$ & $\begin{array}{l}\text { Almari } \\
\text { peralatan } \\
\text { Rak } \\
\text { Closet } \\
\text { Washtafel }\end{array}$ \\
\hline 13. & Chef & $\begin{array}{l}\text { Bekerja } \\
\text { (mem- } \\
\text { buat } \\
\text { menu, } \\
\text { menges- } \\
\text { timasi } \\
\text { harga) } \\
\text { Rapat } \\
\text { Istirahat } \\
\text { Buang air } \\
\text { kecil atau } \\
\text { besar } \\
\text { Beriba- } \\
\text { dah }\end{array}$ & $\begin{array}{l}\text { Kantor } \\
\text { Ruang ra- } \\
\text { pat } \\
\text { Lavatory } \\
\text { Musholla }\end{array}$ & $\begin{array}{l}\text { Kursi } \\
\text { Meja } \\
\text { Showcase } \\
\text { cake and } \\
\text { pastry } \\
\text { Conter } \\
\text { pemesanan } \\
\text { makanan } \\
\text { Pantry set } \\
\text { Almari } \\
\text { untuk } \\
\text { menyimpan } \\
\text { bahan dan } \\
\text { peralatan } \\
\text { Meja untuk } \\
\text { istirahat/ } \\
\text { makan } \\
\text { Kursi untuk } \\
\text { istirahat/ } \\
\text { makan } \\
\text { Closet } \\
\text { Washtafel }\end{array}$ \\
\hline
\end{tabular}

\begin{tabular}{|c|c|c|c|c|}
\hline 14. & $\begin{array}{l}\text { Asistant } \\
\text { chef }\end{array}$ & $\begin{array}{l}\text { Bekerja } \\
\text { Rapat } \\
\text { Istirahat } \\
\text { Buang air } \\
\text { kecil atau } \\
\text { besar } \\
\text { Beriba- } \\
\text { dah }\end{array}$ & $\begin{array}{l}\text { Kantor } \\
\text { Ruang ra- } \\
\text { pat } \\
\text { Lavatory } \\
\text { Musholla }\end{array}$ & $\begin{array}{l}\text { Kursi } \\
\text { Meja } \\
\text { Showcase } \\
\text { cake and } \\
\text { pastry } \\
\text { Conter } \\
\text { pemesanan } \\
\text { makanan } \\
\text { Pantry set } \\
\text { Almari } \\
\text { untuk } \\
\text { menyimpan } \\
\text { bahan dan } \\
\text { peralatan } \\
\text { Meja untuk } \\
\text { istirahat/ } \\
\text { makan } \\
\text { Kursi untuk } \\
\text { istirahat/ } \\
\text { makan } \\
\text { Closet }\end{array}$ \\
\hline 15. & Cooker & $\begin{array}{l}\text { Bekerja } \\
\text { (mema- } \\
\text { sak) } \\
\text { Rapat } \\
\text { Istirahat } \\
\text { Buang air } \\
\text { kecil atau } \\
\text { besar } \\
\text { Beriba- } \\
\text { dah }\end{array}$ & $\begin{array}{l}\text { Kitchen } \\
\text { Ruang ra- } \\
\text { pat } \\
\text { Lavatory } \\
\text { Musholla }\end{array}$ & $\begin{array}{l}\text { Kompor } \\
\text { Oven } \\
\text { Pantry set } \\
\text { Showcase } \\
\text { cake and } \\
\text { Pastry } \\
\text { Rak } \\
\text { Closet } \\
\text { Washtafel }\end{array}$ \\
\hline
\end{tabular}




\begin{tabular}{|c|c|c|c|c|}
\hline 16. & Bar & $\begin{array}{l}\begin{array}{l}\text { Bekerja } \\
\text { (mema- } \\
\text { sak) } \\
\text { Rapat } \\
\text { Istirahat } \\
\text { Buang air } \\
\text { kecil atau } \\
\text { besar } \\
\text { Beriba- } \\
\text { dah }\end{array} \\
\end{array}$ & $\begin{array}{l}\text { Bar } \\
\text { Ruang ra- } \\
\text { pat } \\
\text { Lavatory } \\
\text { Musholla }\end{array}$ & $\begin{array}{l}\text { Water } \\
\text { heater } \\
\text { Rak } \\
\text { Closet } \\
\text { Washtafel }\end{array}$ \\
\hline 17. & Steaward & \begin{tabular}{|l}
$\begin{array}{l}\text { Bekerja } \\
\text { (mencusi } \\
\text { peralatan } \\
\text { dapur) } \\
\text { Rapat } \\
\text { Istirahat } \\
\text { Buang air } \\
\text { kecil atau } \\
\text { besar } \\
\text { Beriba- } \\
\text { dah }\end{array}$ \\
\end{tabular} & $\begin{array}{l}\text { Kitchen } \\
\text { Ruang ra- } \\
\text { pat } \\
\text { Lavatory } \\
\text { Musholla }\end{array}$ & $\begin{array}{l}\text { Mesin pen- } \\
\text { cuci piring } \\
\text { Rak piring } \\
\text { Closet } \\
\text { Washtafel }\end{array}$ \\
\hline 18. & $\begin{array}{l}\text { Gym } \\
\text { staff }\end{array}$ & $\begin{array}{l}\text { Bekerja } \\
\text { (melatih } \\
\text { pengun- } \\
\text { jung } \\
\text { gym) } \\
\text { Rapat } \\
\text { Istirahat } \\
\text { Buang air } \\
\text { kecil atau } \\
\text { besar } \\
\text { Beriba- } \\
\text { dah }\end{array}$ & $\begin{array}{l}\text { Gym area } \\
\text { Lavatory } \\
\text { Musholla }\end{array}$ & $\begin{array}{l}\text { Peralatan } \\
\text { gym }\end{array}$ \\
\hline
\end{tabular}

\begin{tabular}{|c|c|c|c|c|}
\hline 19. & $\begin{array}{l}\text { Enginer- } \\
\text { ing }\end{array}$ & $\begin{array}{l}\text { Bekerja } \\
\text { Rapat } \\
\text { Istirahat } \\
\text { Buang air } \\
\text { kecil atau } \\
\text { besar } \\
\text { Beriba- } \\
\text { dah }\end{array}$ & $\begin{array}{l}\begin{array}{l}\text { Ruang en- } \\
\text { giner }\end{array} \\
\text { Ruang ra- } \\
\text { pat } \\
\text { Lavatory } \\
\text { Musholla }\end{array}$ & $\begin{array}{l}\text { Almari } \\
\text { peralatan } \\
\text { Closet } \\
\text { Washtafel }\end{array}$ \\
\hline 20. & $\begin{array}{l}\text { Exec- } \\
\text { utive } \\
\text { house } \\
\text { keeping }\end{array}$ & $\begin{array}{l}\text { Bekerja } \\
\text { Rapat } \\
\text { Istirahat } \\
\text { Buang air } \\
\text { kecil atau } \\
\text { besar } \\
\text { Beriba- } \\
\text { dah }\end{array}$ & $\begin{array}{l}\text { Kantor } \\
\text { Ruang ra- } \\
\text { pat } \\
\text { Lavatory } \\
\text { Musholla }\end{array}$ & $\begin{array}{l}\text { Meja Kerja } \\
\text { Kursi Kerja } \\
\text { Almari } \\
\text { Arsip } \\
\text { Meja Pen- } \\
\text { gunjung } \\
\text { Meja Rapat } \\
\text { Rak } \\
\text { Closet } \\
\text { Washtafel }\end{array}$ \\
\hline 21. & $\begin{array}{l}\text { Room } \\
\text { boy }\end{array}$ & $\begin{array}{l}\text { Bekerja } \\
\text { Rapat } \\
\text { Istirahat } \\
\text { Buang air } \\
\text { kecil atau } \\
\text { besar } \\
\text { Beriba- } \\
\text { dah }\end{array}$ & $\begin{array}{l}\text { Ruang per- } \\
\text { alatan } \\
\text { Ruang ra- } \\
\text { pat } \\
\text { Lavatory } \\
\text { Musholla }\end{array}$ & \begin{tabular}{|l}
$\begin{array}{l}\text { Almari } \\
\text { peralatan }\end{array}$ \\
Closet \\
Washtafel
\end{tabular} \\
\hline
\end{tabular}




\begin{tabular}{|c|c|c|c|c|}
\hline 22. & Gardener & $\begin{array}{l}\begin{array}{l}\text { Bekerja } \\
\text { (men- } \\
\text { gatur } \\
\text { taman) }\end{array} \\
\text { Rapat } \\
\text { Istirahat } \\
\text { Buang air } \\
\text { kecil atau } \\
\text { besar } \\
\text { Beriba- } \\
\text { dah }\end{array}$ & $\begin{array}{l}\text { Taman } \\
\text { Ruang ra- } \\
\text { pat } \\
\text { Lavatory } \\
\text { Musholla }\end{array}$ & $\begin{array}{l}\text { Meja Rapat } \\
\text { Rak } \\
\text { Closet } \\
\text { Washtafel }\end{array}$ \\
\hline 23. & $\begin{array}{l}\text { Publik } \\
\text { area } \\
\text { service }\end{array}$ & 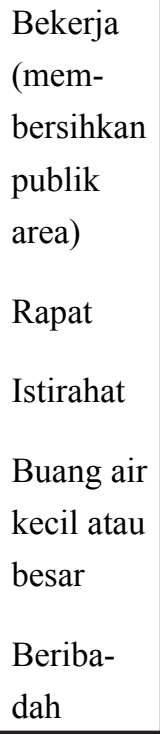 & $\begin{array}{l}\text { Publik area } \\
\text { Ruang ra- } \\
\text { pat } \\
\text { Lavatory } \\
\text { Musholla }\end{array}$ & $\begin{array}{l}\text { Meja Rapat } \\
\text { Rak } \\
\text { Closet } \\
\text { Washtafel }\end{array}$ \\
\hline 24. & Security & $\begin{array}{l}\begin{array}{l}\text { Bekerja } \\
\text { (menjaga } \\
\text { keaman- } \\
\text { an) }\end{array} \\
\text { Rapat } \\
\text { Istirahat } \\
\text { Buang air } \\
\text { kecil atau } \\
\text { besar } \\
\text { Beriba- } \\
\text { dah }\end{array}$ & $\begin{array}{l}\text { Kantor } \\
\text { Ruang ra- } \\
\text { pat } \\
\text { Lavatory } \\
\text { Musholla }\end{array}$ & $\begin{array}{l}\text { Meja Kerja } \\
\text { Kursi Kerja } \\
\text { Meja Rapat } \\
\text { Rak } \\
\text { Closet } \\
\text { Washtafel }\end{array}$ \\
\hline
\end{tabular}

\begin{tabular}{|c|c|c|c|}
\hline 25. & $\begin{array}{l}\text { Pengun- } \\
\text { jung }\end{array}$ & $\begin{array}{l}\text { Cek in } \\
\text { Istirahat } \\
\text { Spa } \\
\text { Meeting } \\
\text { Bersantai } \\
\text { Makan / } \\
\text { minum } \\
\text { Buang air } \\
\text { besar / } \\
\text { kecil } \\
\text { Beristira- } \\
\text { hat }\end{array}$ & $\begin{array}{l}\text { Lobby } \\
\text { Area spa } \\
\text { Restaurant } \\
\text { Me eting } \\
\text { Room } \\
\text { Kamar ti- } \\
\text { dur } \\
\text { Taman } \\
\text { Area ter- } \\
\text { buka } \\
\text { Lavatory }\end{array}$ \\
\hline
\end{tabular}

\section{Hubungan Antar Ruang}

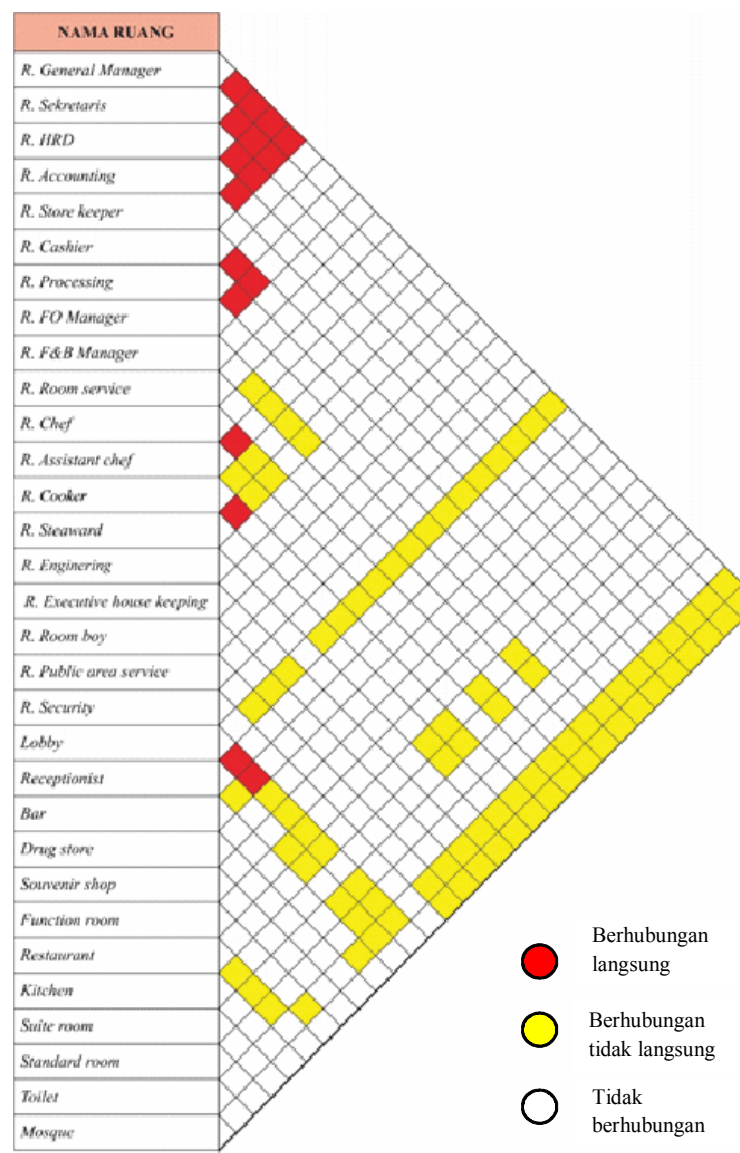

Gambar 4. Hubungan Antar Ruang Hotel Lampion di Surakarta 


\section{Grouping zoning dan sirkulasi dan Sirkulasi}

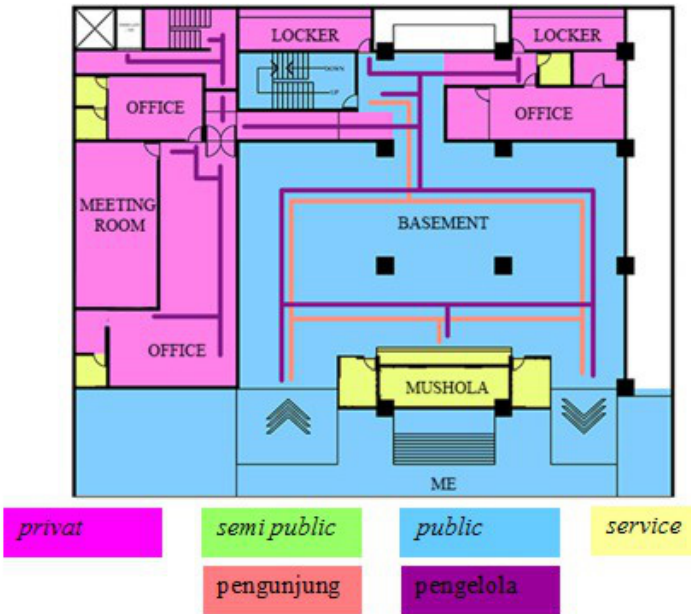

Gambar 5. Grouping zoning dan sirkulasi basement

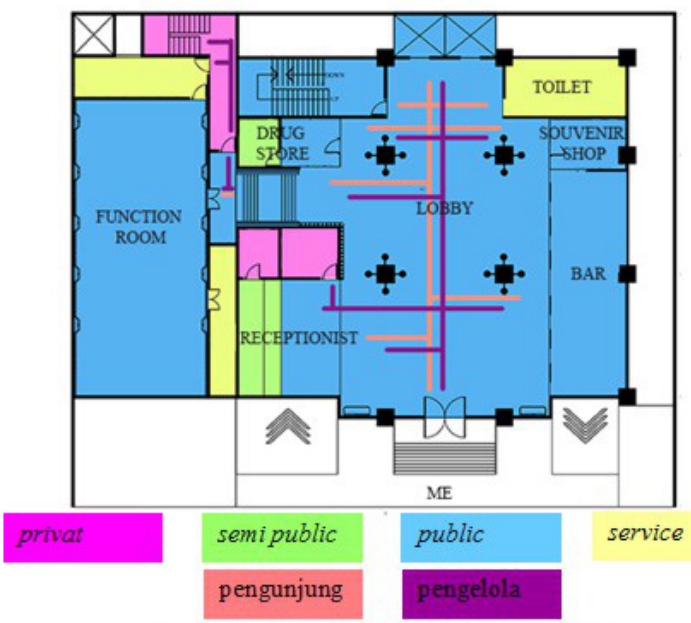

Gambar 6. Grouping zoning dan sirkulasi lantai 1

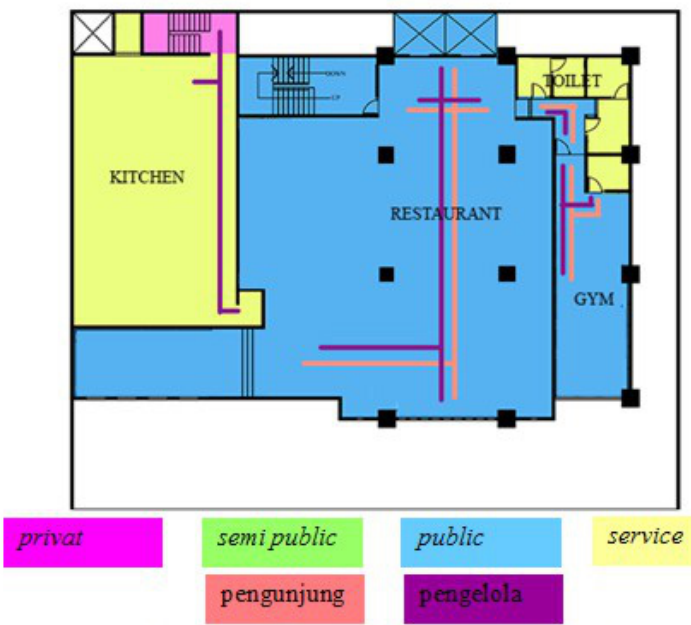

Gambar 7. Grouping zoning dan sirkulasi lantai 2

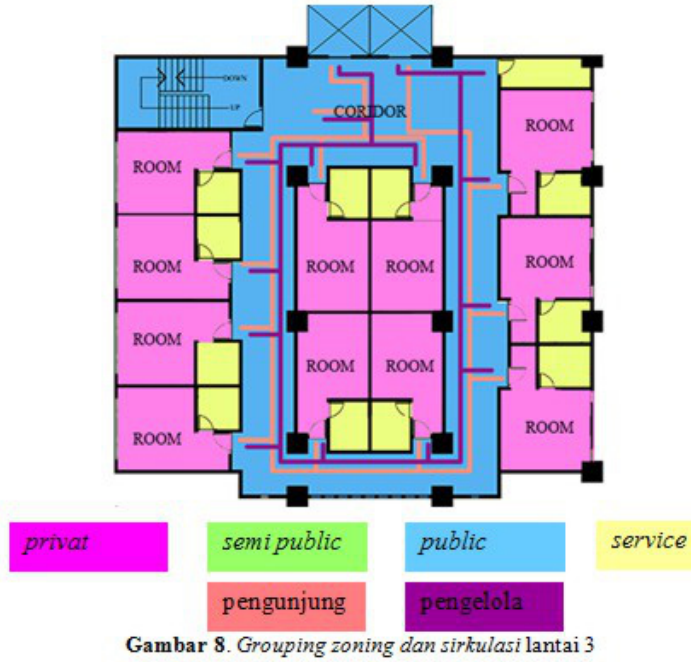

Gambar 8. Grouping zoning dan sirkulasi lantai 3

Layout

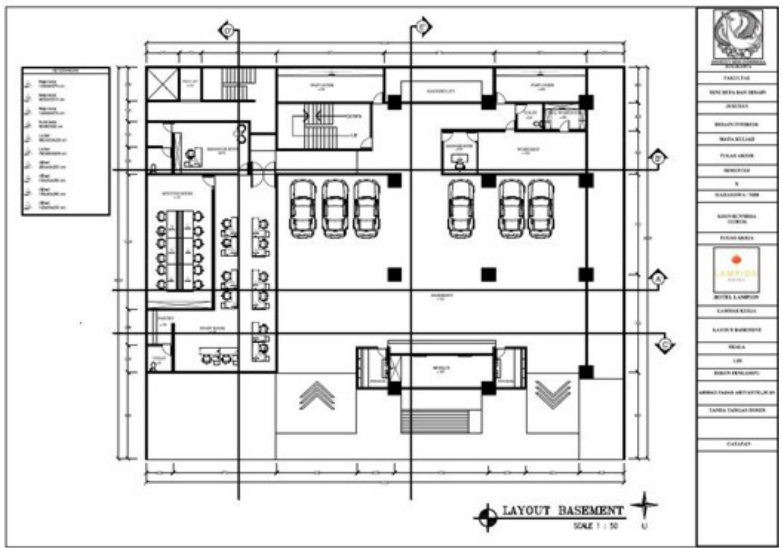

Gambar 10. Layout Basement

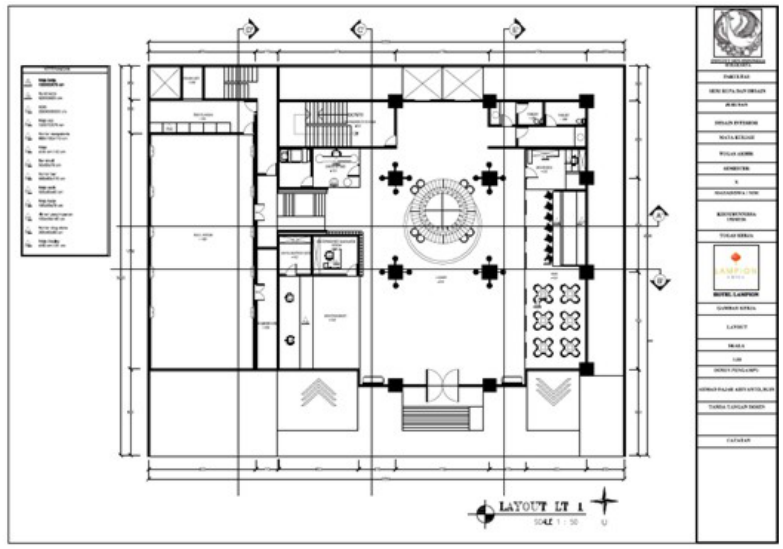

Gambar 11. Layout Lantai 1 


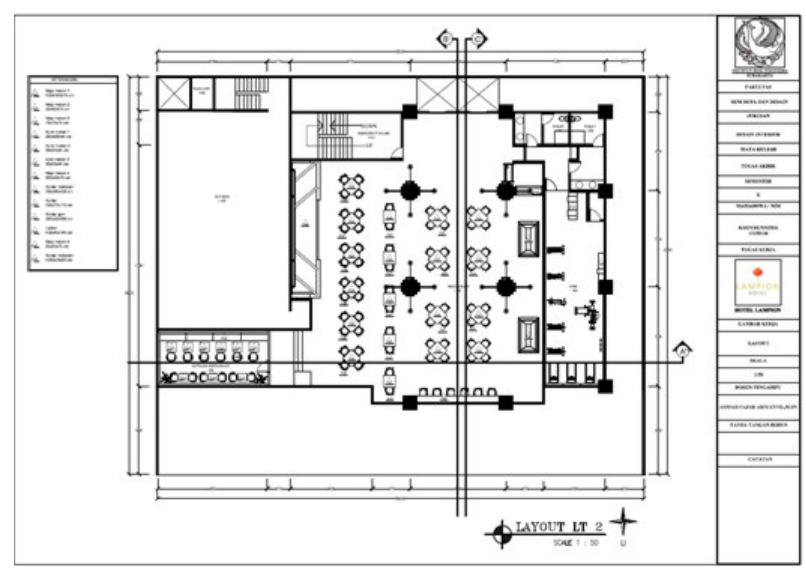

Gambar 12. Layout Lantai 2

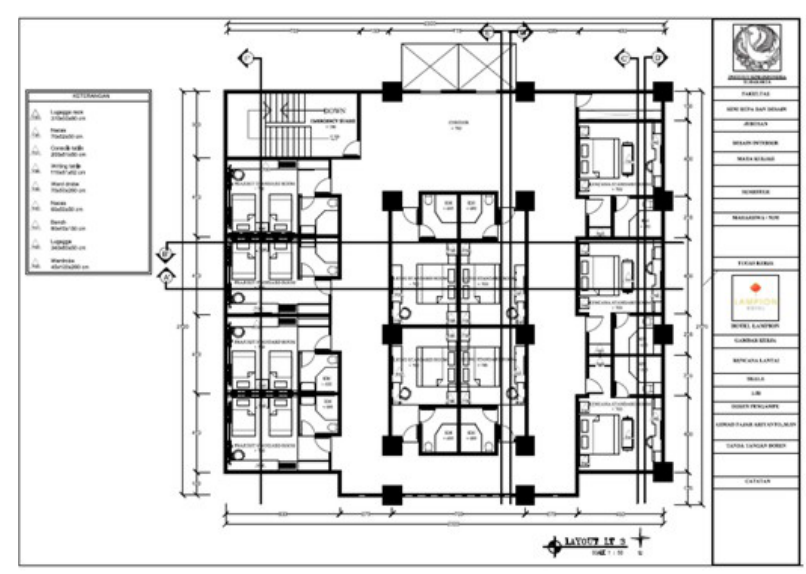

Gambar 13. Layout Lantai 3

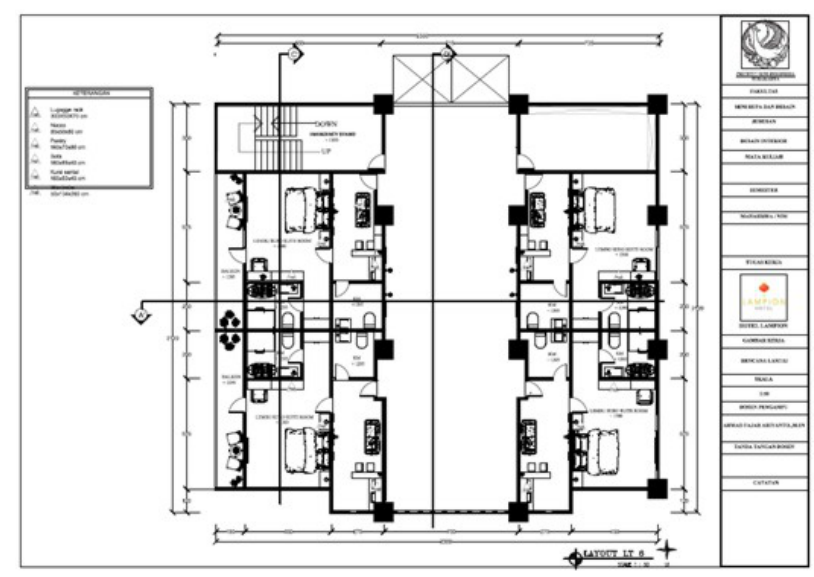

Gambar 14. Layout Lantai 6

\section{F. Tema dan Gaya}

Pada penerapan re-desain interior Hotel Lampion di Surakarta pengkarya memilih Grebeg Sudiro sebagai pengisi tema hotel.
Grebeg sudiro merupakan event tahunan yang diadakan oleh pemkot kota Surakarta. Awal mula Grebeg Sudiro lahir dikarenakan terbentuknya akulturasi budaya yang sangat kuat antara etnis Tionghoa yang berada di Sudiroprajan $^{7}$ dengan masyarakat lokal untuk memperkokoh kampung Sudiroprajan sebagai kampung pluralisme ${ }^{8}$.

Pada acara Grebeg Sudiro biasanya menampilkan beberapa jodhang yang berisi hasil unggulan kampung Sudiroprajan seperti janggelut, gembukan, onde-onde, sayur mayur dan buah-buahan. Jodang yang wajib yaitu kue keranjang yang merupakan makanan khas masyarkat Tionghoa yang biasanya di desain menyerupai bangunan monumental di Pasar Gede atau Kelenteng. Selain makanan khas ada juga tarian-tarian khas dari Tionghoa yaitu barongsai dan liongsai atau tarian dari jawa yaitu reog. Pada acara Grebeg Sudiro yang akan diangkat untuk dijadikan tema pada Re-desain interior Hotel Lampion di Surakarta ini adalah sebagai berikut :

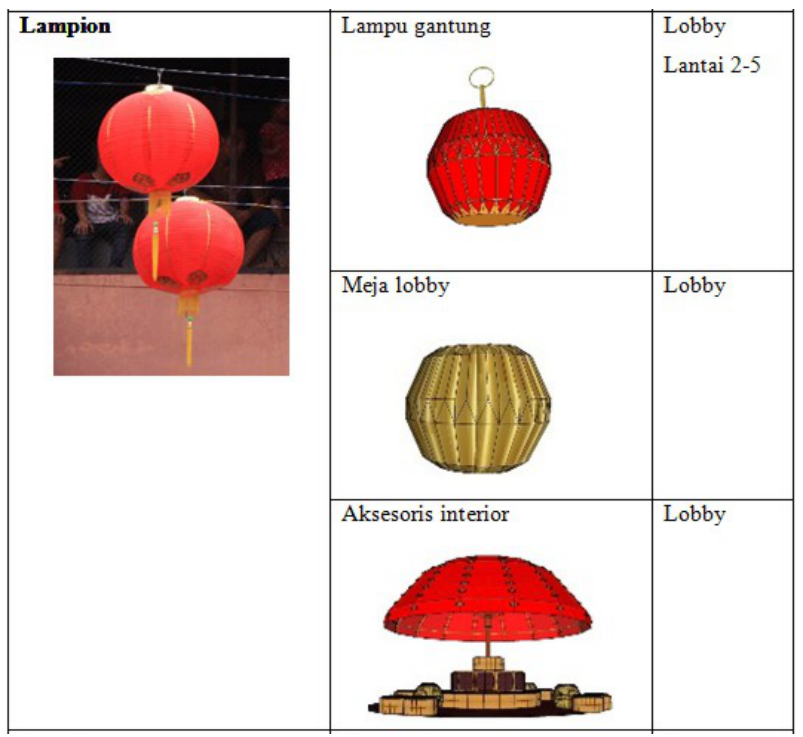

$7 \quad$ Salah satu nama kelurahan yang merupakan kawasan pecinan di surakarta

$8 \quad$ Henri susanto ketua pencetus Grebeg Sudiro (ketua klenteng Tien Kok Sie) 


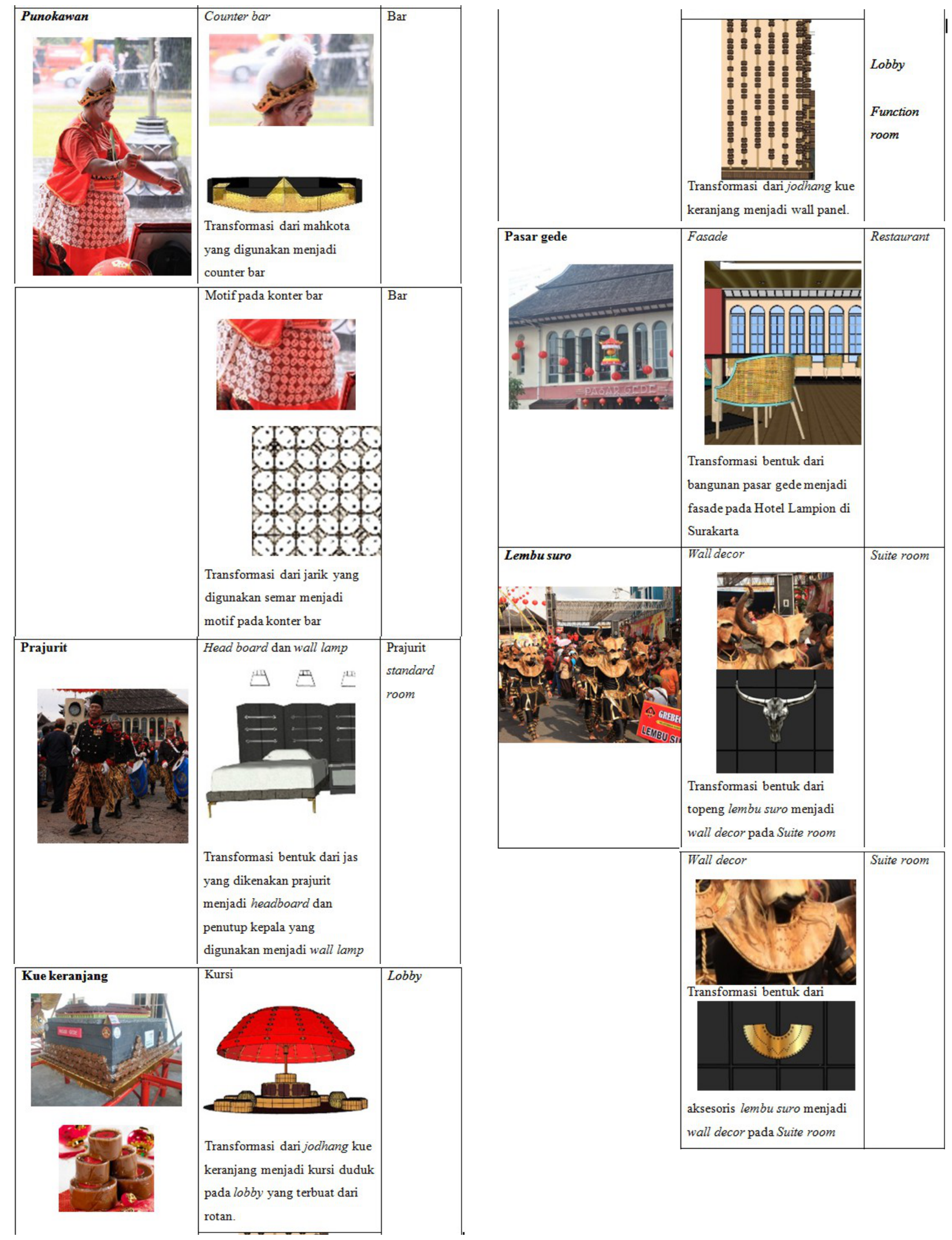




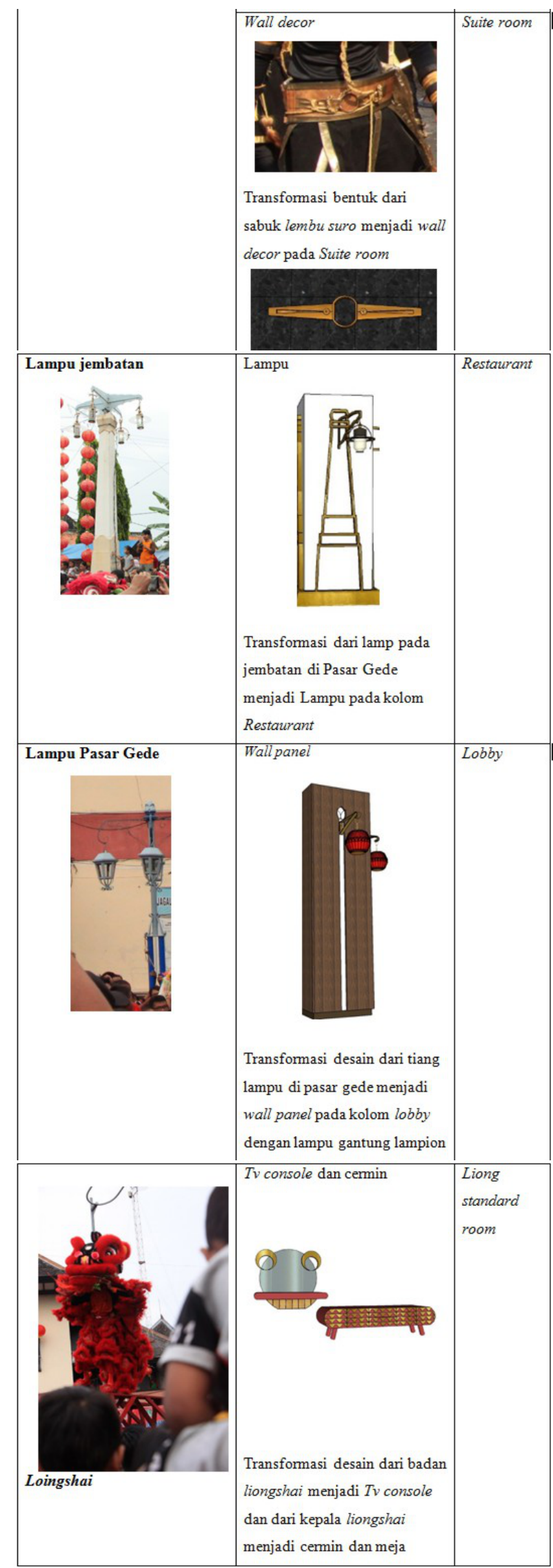

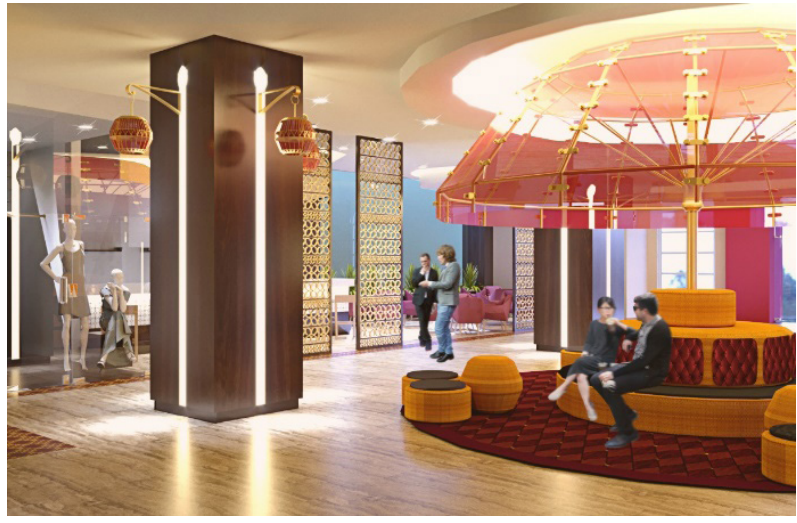

Gambar 15. Gambar perspektif Lobby Hotel Lampion di Surakarta

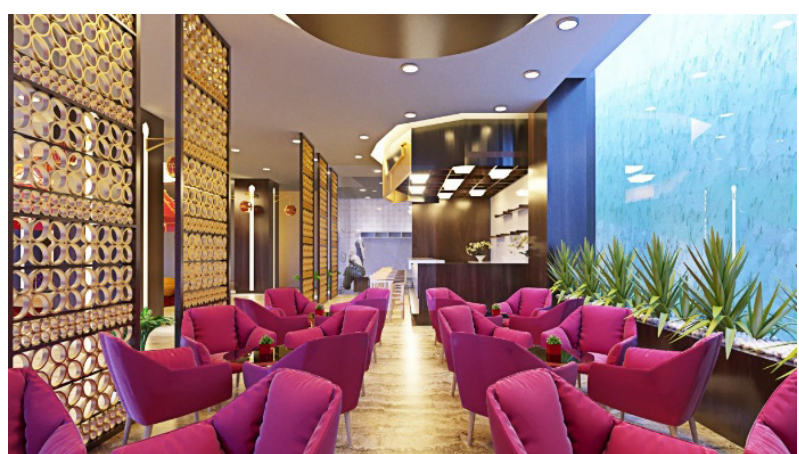

Gambar 16. Gambar perspektif Bar Hotel Lampion di Surakarta

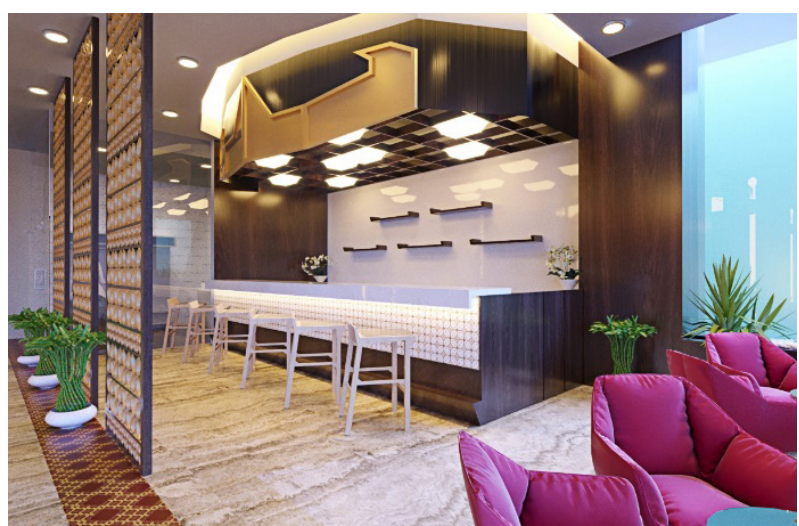

Gambar 17. Gambar perspektif Bar Hotel Lampion di Surakarta 


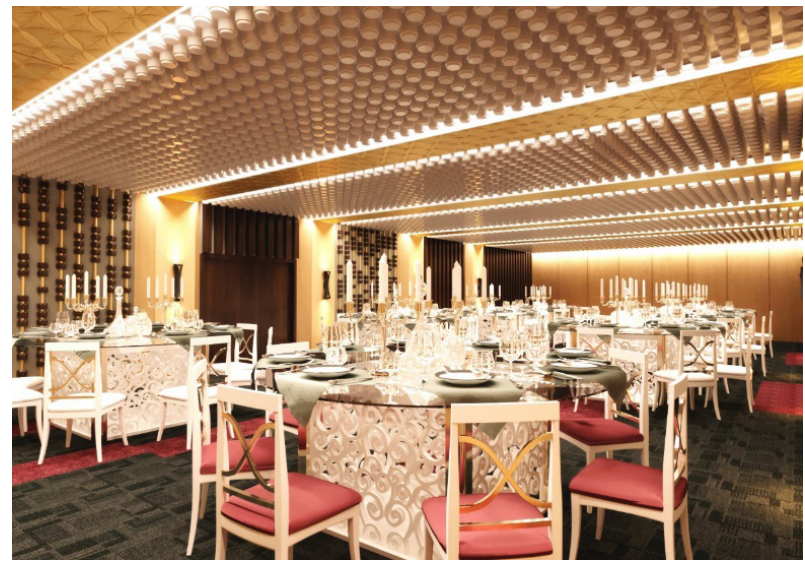

Gambar 18. Gambar perspektif Function Room Hotel Lampion di Surakarta

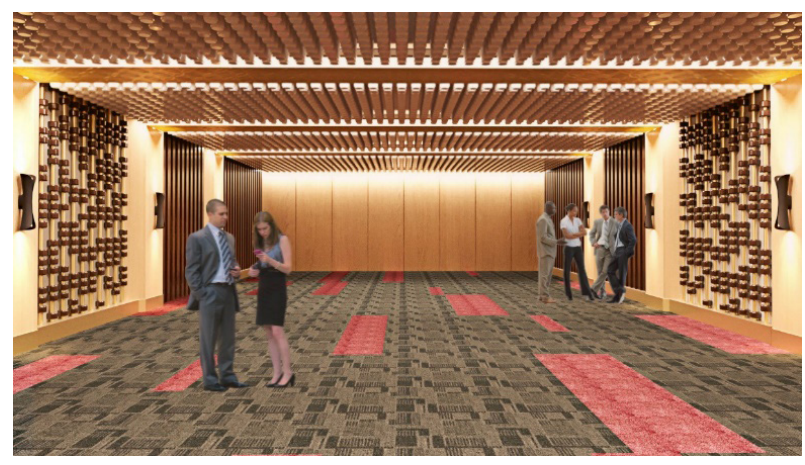

Gambar 19. Gambar perspektif Function Room Hotel Lampion di Surakarta

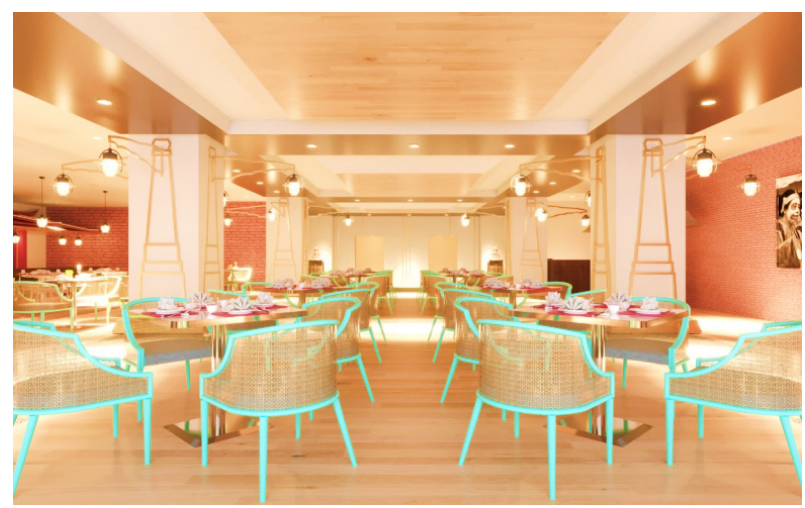

Gambar 20. Gambar perspektif Restaurant Hotel Lampion di Surakarta

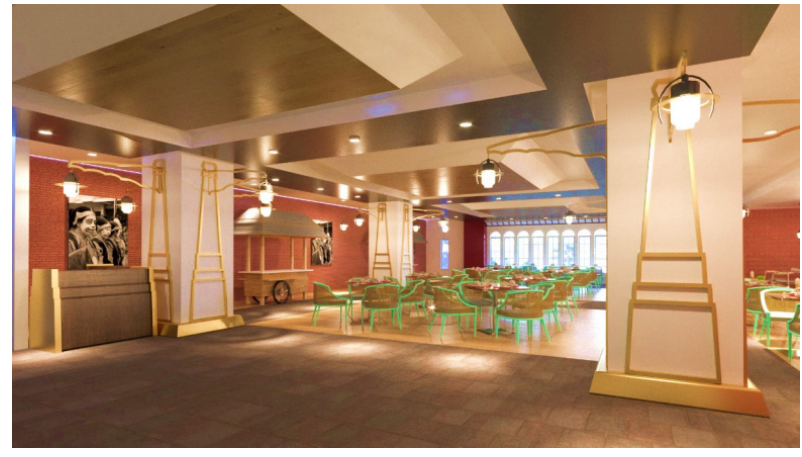

Gambar 21. Gambar perspektif Restaurant Hotel Lampion di Surakarta

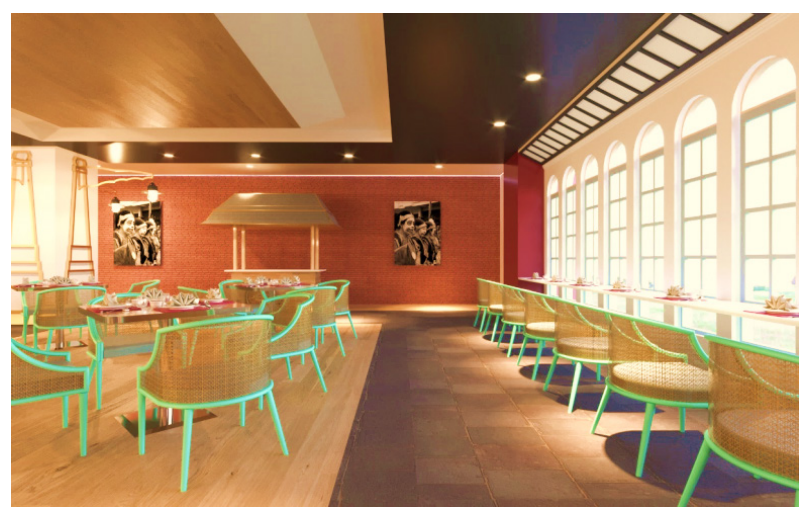

Gambar 22. Gambar perspektif Restaurant Hotel Lampion di Surakarta

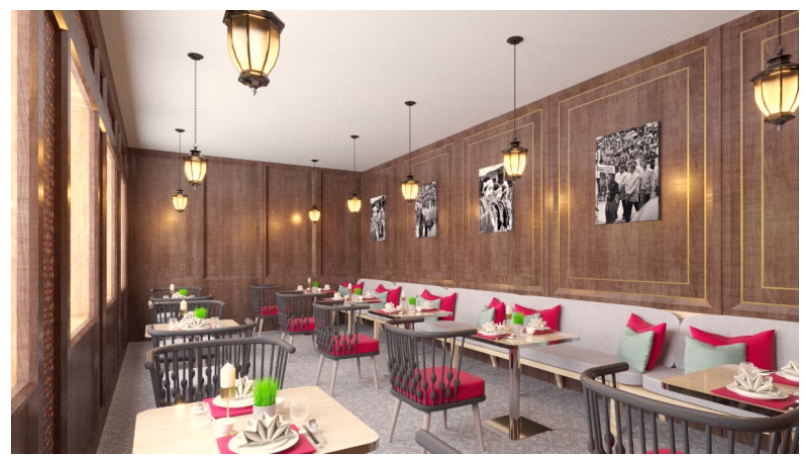

Gambar 23. Gambar perspektif Restaurant Hotel Lampion di Surakarta 


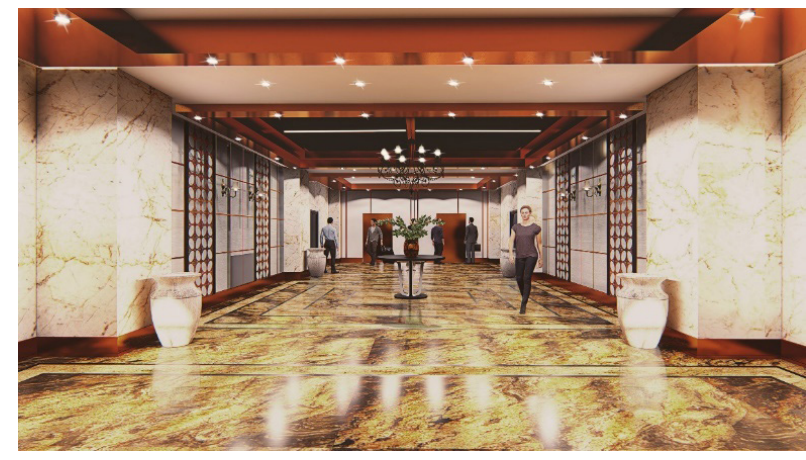

Gambar 24. Gambar perspektif Coridor Suite room Hotel Lampion di Surakarta

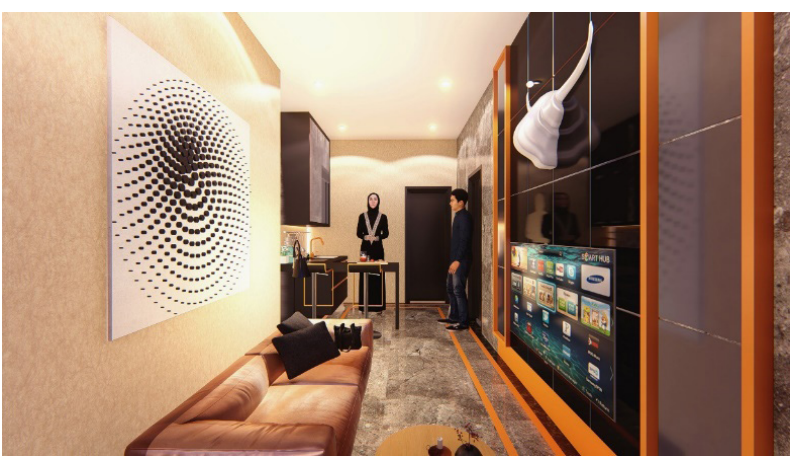

Gambar 25. Gambar perspektif Ruang Tamu Suite room Hotel Lampion di Surakarta

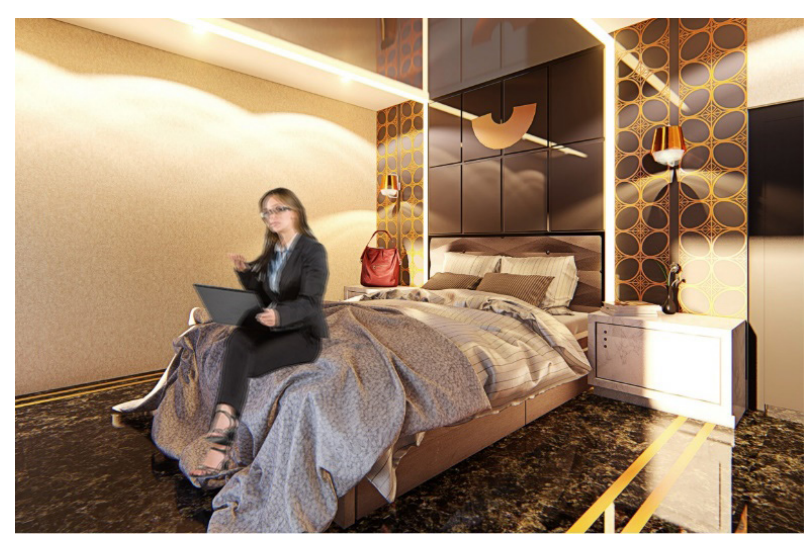

Gambar 26. Gambar perspektif Ruang Tidur Suite room Hotel Lampion di Surakarta

\section{SIMPULAN}

Re-desain interior Hotel Lampion di Surakarta adalah upaya meningkatkan Hotel Lampion di Surakarta yang berbintang 2 menjadi hotel berbintang 3 adalah dengan cara menambah beberapa fasilitas dan mengubah interior hotel menjadi lebih bercitra lokal.

Penambahan fasilitas pada Hotel Lampion di Surakarta adalah penambahan fasilitas : Bar, suite room, drug store, souvenir shop dan sarana olahraga. Penambahan fasilias tersebut berdasarkan peraturan pemerintah dan data literatur tentang standard hotel berbintang. Dengan adanya penambahan fasilitas tersebut diharapkan Hotel Lampion di Surakarta dapat meningkatkan standardnya dari hotel berbintang 2 menjadi hotel berbintang 3. Selain penambahan beberapa fasilitas interior pada Hotel Lampion juga perlu adanya perubahan agar bercitra lokal.

Re-desain interior Hotel Lampion di Surakarta diharapkan mampu menjadi alternatif desain Hotel yang mampu memfasilitasi pengguna dan mampu mengangkat nilai budaya bangsa.

\section{DAFTAR PUSTAKA}

\section{Buku}

Departemen Pendidikan Nasional. 2001. Kamus Besar Bahasa Indonesia Edisi III. Jakarta: Balai Pustaka.

De Chiara, Joseph dan John Hancook Callender. 1980. Time Saver Standart for Building Types. dalam Ahmad Fajar Interior hotel syariah. New York: Mc Graw Hill.

D.K. Ching, Francis. 1996. Ilustrasi Desain Interior. Jakarta: Penerbit Erlangga.

Fajar, Ahmad Ariyanto. 2012. Desain Interior Hotel Syariah. ISI Surakarta. 
Marlina, Endy. 2008. Panduan Perencanaan bangunan komersil. CV Andi Offset.

M. Echols, John dan Hasan Sadily. 1990. kamus Inggris Indonesia. Jakarta: PT. Gramedia.

Neufert, Ernst. 1975. Architcts Data. Great Brittain: Granada Publishing.

Sujanto, Bambang, 2008. Hotel Courtesy The Secret of 5 Star Hotel Courtesy. Yogyakarta: Penerbit Andi.

Sulastiono, Agus. 2008. Manajemen Penyelenggaraan Hotel Bandung: Alfabeta.

Sunarmi. 2001. Ergonomi dan Aplikasinya Pada Kriya. Surakarta: STSI Surakarta.

Suptandar, J. Pamudji. 1999. Disain Interior Pengantar Merancang Interior Untuk Mahasiswa dan Arsitektur. Jakarta: Djambatan.

Nugroho,Sarwo. 2015. Managemen Warna Desain, Yogyakarta

\section{Tugas akhir}

Clarasatati, Tissana. Tradisi Grebeg Sudiro di Sudiroprajan. Karya Tugas Akhir Universitas Sebelas Maret. 2013.

\section{Wawancara}

Septi, 38 tahun, ketua grebeg sudiro tahun 2016-2017, Surakarta, 2017

Henri, Pencetus Grebeg Sudiro, Surakarta, 2017

\section{Internet}

http://www.kbbi.kemdikbud.go.id/entri/Lampion 13-07-2018 12.58 WIB

http://www.surakarta.go.id/konten/hotel-di-solo / 29 Mei 2016/ 10.11 WIB

http://www.surakarta.go.id/konten/slogan-surakarta/29-05-2016/ 09.00 WIB 